rev.relac.int.estrateg.segur.13(1):147-162,2018

\title{
Insecurity and its impact on tourism in Guerrero: a spatial approach, 1999-2014*
}

\author{
Roldán Andrés-Rosales** \\ Luis Alberto Sánchez-Mitre*** \\ José Nabor Cruz Marcelo ${ }^{* * *}$
}

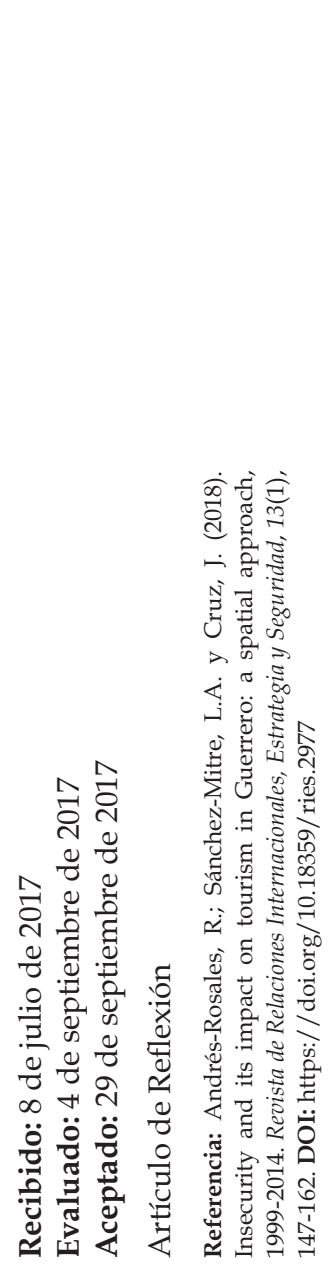

\begin{abstract}
Insecurity has led to slow growth in the different regions in Mexico. But it has influenced much more in the touristic areas of the country. This is the case of the municipality of Acapulco Guerrero, place considered as one of the most insecure worldwide. Through the prevalent information on insecurity in the municipalities of the country available in the National Institute of Geography and Statistics (INEGI for its acronym in Spanish) and the information on the income of tourism provided by SESNSP of the period 1999-2014, we constructed an index of violence, which shows that the highest concentration of insecurity is located in Acapulco and Chilpancingo principally. This problem has negatively influenced the growth of the region, given its significant impact on tourism.

This paper is a product from the work of the Institute of Economic Research, Universidad Nacional Autónoma de México (UNAM).

** Conacyt researcher and professor at the Faculty of Higher Studies Acatlan, Universidad Nacional Autónoma de México (UNAM). E-mail: roldandres@apolo.acatlan.unam.mx

*** Bachelor's Degree Student at the Faculty of Higher Studies Acatlan, Universidad Nacional Autónoma de México (UNAM). E-mail: l.alberto.mitre@gmail.com

$* * *$ Researcher at the Institute of Economic Research, Universidad Nacional Autónoma de México (UNAM). E-mail: jnabor@unam.mx
\end{abstract}


Keywords: Insecurity; tourism; economic growth.

JEL Classification: O18, O40, O47, R11, R12 and Z32

\section{La inseguridad y su impacto en el turismo en Guerrero: un enfoque espacial, 1999-2014}

\section{Resumen}

La inseguridad ha ocasionado un lento crecimiento en las diferentes regiones mexicanas. Pero ha influido mucho más en las zonas turísticas del país, ejemplo de ello es el municipio de Acapulco Guerrero, lugar considerado como una de las más inseguras a nivel internacional. Mediante la información prevaleciente sobre la inseguridad en los municipios del país disponible en el Instituto Nacional de Estadística y Geografía (INEGI) e información sobre el ingreso del turismo que proporciona SESNSP del periodo 1999-2014, construimos un índice de violencia con el que mostramos que la mayor concentración de la inseguridad se localiza en Acapulco y Chilpancingo principalmente, y que este problema ha influido negativamente en el crecimiento de la región dado su impacto significativo en el turismo.

Palabras clave: inseguridad; turismo; crecimiento económico.

\section{Insegurança e seu impacto no turismo em Guerrero: uma abordagem espacial, 1999-2014}

\section{Resumo}

A insegurança levou a retardar o crescimento em diferentes regiões do México. Mas tem influenciado muito mais em áreas turísticas do país, exemplo é o município de Acapulco Guerrero, um lugar considerado um dos mais inseguros internacionalmente. Pela informação que prevalece sobre a insegurança em municípios do país disponíveis no INEGl e informações sobre turismo de renda proporciona SESNSP do período 1999-2014, construímos um índice de violência com que vamos mostrar que a maior concentração de insegurança esta localizadas principalmente em Acapulco e Chilpancingo, e este problema tem influenciado negativamente o crescimento da região dado ao seu impacto significativo no turismo.

Palavras-chave: Insegurança; turismo; crescimento econômico. 


\section{Introduction}

From the 1950s to 1970s, the Mexican tourism boom began in AcapulCo, Guerrero, under the government of President Miguel Aleman (19461952); he was looking forward to having a place in Mexico that could be a national and international destination and began to lay the foundations for developing it as a touristic destination. However, it was not from 1980 to 2000 that this municipality became the primary, national and international destination of the country. In recent years, Acapulco is only visited mostly by domestic tourism because of the growing and widespread violence and insecurity.

The growing insecurity and drug trafficking observed during President's Felipe Calderon administration (20062012) have significantly influenced the country's economic growth, but the most affected cities have been those with international attractiveness, such as Acapulco. This insecurity has greatly impoverished municipalities, whose primary source of growth and development is the international and national tourism.

In this work, we are focused on the economic growth trend that affects the state of Guerrero in the last years, and we relate it with some indicators such as the prevailing insecurity in the entity, currently classified as one of the most dangerous in the world. Also, we analyze its productive structure and its direct and indirect impact on tourism growth. Unlike other studies that relate economic growth to tourism, we will focus on how this activity has been adversely affected by increased insecurity from a spatial perspective.

According to the Ministry of Tourism (SECTUR for its acronym in Spanish), we found that in 2014, Mexico City presented a share of almost $17 \%$ of total employment generated by tourism in the country. In the same year, Jalisco had approximately $8 \%$, the State of Mexico almost 7\%, Veracruz 5\%, and Guerrero received only $2 \%$ of the national total. The highest percentages of the average rate of employment growth generated by tourism from 2004 to 2014 were observed in Chiapas with a rate of $8.6 \%$, Mexico State $8.5 \%$, Querétaro 8.2\%, and Tabasco 8.2\%. Referring to the percentage share of tourism from total GDP of the entity, we found that in 2014, Quintana Roo had a $44 \%$ share respect to its GDP, while Baja California Sur and Nayarit accounted for 28\%; in Guerrero, it was $21 \%$ and almost $19 \%$ in Morelos. The highest observed average growth of the tourism sector was observed in Morelos with almost 12\%, San Luis Potosí 10\%, Nayarit almost 9\% and Guanajuato $7.6 \%$. In Guerrero, this growth was only $0.33 \%$. We observe that the growth of the tourism sector has been lower than the national average in this entity, which could be a first account of how the prevailing insecurity causes poor economic performance.

Given the importance of tourism in job's creation, we are focusing on stu- 
dying its trend in the city of Acapulco, Guerrero. In this way, we can detect the direct impact of the insecurity on the growth of the region.

The present work is divided into three main sections. In the first one, we address the regional importance, economic growth and its links with tourism and the prevailing insecurity in the Mexican economy. In the second section, we describe the information used in the models and perform an exploratory analysis of the insecurity in the entity, where we show the municipalities that presented a high-growth of this problem and the ones with a reduction of it. In this section, we also describe the importance of the spatial approach within the regional studies. In the third part, we present the empirical evidence, where we obtain the main findings of the work. Finally, we give our conclusions.

\section{Theoretical background of the region and economic growth}

Since activities develop in space, and different localities and areas have nonhomogeneous characteristics that often are not included in an economic or econometric model. With the regional studies, we analyze the activities carried out in these spaces taking into account their particular characteristics such as society, area, culture, type of people who inhabit it, its geographical position, its socioeconomic structures, issues generated from the interaction of individuals, among other factors. Defi- ning a region varies according to the author and approach under which the study is conducted; Richardson (1986) points out that a region is conceived as a set of different nodes of different sizes (cities, towns, villages and sparsely populated rural areas) linked functionally and structurally.

Within the regional analysis, there are different classifications and definitions more disaggregated than the previous description of a region. Czamanski (1973) makes a conceptualization and divides it up to reach differences between area and region; for example, by zone. He refers to a zone by "a latitudinal belt obtained by a cut in a sphere," although it is currently used to distinguish a place that has different characteristics from the space surrounding it. While he defines a region as "an area within of the national economy, with a structure sufficient and complete to operate independently, although it maintains close ties with the rest of the economy." By region, we refer to a particular space that has its own and different characteristics from the others, which means that the distribution of natural resources is heterogeneous. Polése (1998), mentions that the intrinsic features of the region will be the cause of differences between regions. According to this author, these differences are because the resources are not evenly distributed throughout the territory. Some areas have higher advantages than others concerning the wealth of natural resources. This phenomenon causes people and companies to migrate from one place to 
another searching for better opportunities for their development and personal well-being.

Regional development and growth are closely linked to economic geography. Fujita (2000) mentions that geographical research is dedicated to the study of the causes of economic activities taking place at a precise location. It means that by the attractiveness of each region, some can concentrate manufacturing activities, like some areas of the north and center of Mexico do. Cities like Monterrey, Nuevo Leon, San Luis Potosí, Guadalajara, Querétaro and the State of Mexico, are the main ones that attract industries. While the tertiary activity, mostly the financial activity has been concentrated in Mexico City. But regions that have natural resources and a privileged geographic position have other factors and events that drive its economic growth and development. As an example, we have Acapulco, Guerrero, a city that makes use of its natural advantages such as climate, and the characteristics of the sea. This advantage tends to potentiate it as an international tourist destination, meaning that the motor that potentiates its growth is different and not limited to the development and growth of the manufacturing industry, as stated by Kaldor's laws (1984).

Considering that the growth of the regions comes from different sources, we will focus on the areas or spaces that are dedicated to tourism, specifically, in Acapulco, Guerrero. First of all, because it is one of the most demanded destinations by the national tourism and secondly because it is considered one of the most dangerous international tourist destinations.

Tourism is one of the most growing sectors of the world economy, which can promote much of the economic development either directly or indirectly. Directly when it stimulates the activities related to the service sector, like great hotel's complexes, restaurants and people focused on offering recreational and touristic services. Indirectly when it influences the growth of the primary and secondary sectors by the goods that are produced by the former and consumed (demanded) by visitors. Services increase the income of the beneficiary entity or region since it stimulates the aggregate request of the revenue obtained by this item. It means that the expenditure that the tourist makes in the national territory represents an initial injection in the economy, translated into income perceived by the factors of production of the tourist sector, which in turn gives indirect effects in the marketplace. This is because a portion of these revenues is used for the purchase of goods and services for the operation of the industry itself. Those payments made on the acquisition of property and services, in turn, creates induced effects because those who receive this income is also used for the payment of goods and services and thus successively (Alfaro Navarro and López Ruiz, 2008).

Almirón, Bertoncello, Kuper and Ramirez (2008, p. 13) believe that 


\begin{abstract}
[...] tourism is seen as an economical alternative, which allows the generation of income and land redistribution, this requires fewer investment costs compared to other activities and contributes to transform the productive structure and to diversify the economy. Tourism is proposed as an instrument for generating jobs by attributing the capacity to absorb large volumes of work: travel often appears as an 'economic alternati$v^{\prime}$ for traditional productive sectors such as the agricultural sector.
\end{abstract}

particularly for territories that do not have the potential to attract either industry or specialized services. Since agrarian activity in Mexico, specifically in the south part of the country, is traditional and for subsistence, it cannot be the development or growth of the region; then tourism is considered an excellent alternative to enter the path of active and sustained development of the weak areas of Mexico.

Many regions share similar problems even though there are regional heterogeneity and natural advantages. One of these issues is the prevailing insecurity that has intensified during the last years, which not only affects the growth dynamics of the different states of the country but also limits their development. Hence, it is one of the significant challenges that the various states of the country and municipalities face today and that have not been solved.

The tourist activity not only influences economic factors, but it also generates social enrichment known as "sociocultural positivities." Tourism is presented as a "social choice" to prevent population migration, enhances the common heritage and local identity, raises public awareness about the care of their resources and transforms their social reality (Almirón et al., 2008).

Although there may be many positive factors generated by tourism, this does not exclude that there are also negative ones that undermine the economic development, generating a deterioration of the economy, society, and culture (negative impacts include increased pollution, drug addiction, prostitution, etc.). Thus, the economic growth of the regions is not sufficient; the growth must be translated into development. Within the conceptualization of economic development, this concept evolves and is transformed as society does, as countries, regions, and cities provide solutions to new problems, innovations and knowledge are disseminated within economic organizations and social (Vázquez, 2006).

Citizen security has been affected in different regions of the country, which has had an adverse impact on national and international tourism. This type of insecurity implies high social, and economic costs for the different regions, local governments, and municipal presidents, and becomes an impossible problem to solve since they lack economic resources and infrastructure to counter this problem. The insecurity directly affects the citizens of the region, the smooth functioning of busi- 
ness and limits reinvestment of funds. Thus, the effects generated by insecurity are the increase of production costs, reduction of regional income and productivity, limited growth and limited economic spillovers, among others (Figueroa, Montes de Oca, Artavia and Marshall, 1997).

One of the main problems of public policy today is the one regarding the eradication of violence and insecurity in Mexican society, although the Government has created several strategies to combat insecurity, most of them have unfavorable or null results. The search for a solution to insecurity has become a crucial issue on the government agenda.

The problems mentioned above not only slow economic activity itself but also prevents society from its development, since it slows human capital, impoverishes families, limits new opportunities for young people and worsens problems such as social exclusion and income distribution. These factors generate stagnation in the region, and the society enters a vicious circle of poverty and fewer opportunities.

Insecurity situations not only affect a region's inhabitants, but it also extends its effects far beyond its border, even to areas that are not engaged in tourism. Polése (1998) believes that the regions within a country are more dynamic since they are much more open, and goods flow more since there are not as many barriers as those found in an international context. This freedom makes the spread of problems, such as insecurity more natural; this is the case of Mexico. Insecurity has crossed all the states of the country; there is not a single case of a state without this national problem ${ }^{1}$.

Among the works that highlight the importance of tourism for the Mexican economy, we find the one of Sánchez and Cruz (2016). They expose a relationship between the exchange rate and the evolution of the US economy and the flow of travelers to Mexico since a large percentage of travelers come from the United States of America. On the other hand, Sánchez and Cruz (2017) present a link between the recent insecurity and its effect on the tourism in Mexico, and the authors argue that the number of kidnappings reported between 1997 and 2016 has negatively affected the flow of international travelers/tourists/hikers to the country. Kidnappings increased significantly since 2010. Finally, Polanco and Torres (2017) analyze the relationship of criminal activity in the tourist destinations of Mexico.

As recognized by members of the tourism industry, the criminal acts observed in the 32 states of the Mexican Republic have a direct impact on the tourist activity. Therefore, it limits the

This is the case of Merida, where insecurity has begun to increase. It was considered in previous years the safest city in the country. 
arrival of a more significant number of visitors. Further, the US government has issued travel alerts, which impacted much more on the visits of American tourists to our country. In recent and specific cases, the states of Jalisco, State of Mexico, Guerrero, Michoacán, and Veracruz, have been affected by the mentioned alerts. For the US government, these states are considered as high risk for visitors (specifically in 2015). Roemer (2012) says that crime is a severe problem in the society, which generates irreversible damage to its victims, to the families of the victims and community as a whole. Also, the insecurity causes fear in the population of the region, and when this happens, the alienation of the society from the authorities is inevitable. In summary, citizen's confidence decreases as the insecurity increases; crime and fear impede economic development. At the microeconomic level, crime reduces the formation of human capital because it induces some individuals to develop criminal skills rather than socially productive activities. In the macroeconomic framework, it reduces certainty, undermines confidence and thus, discourages domestic and foreign investment (Roemer, 2012).

In general, we can say that the government must guarantee the safety of individuals, the protection of life, human rights and properties, under which the state justifies its monopoly over the legitimate use of force. Therefore, when the state fails to meet this primary function, its legitimacy is eroded (Estrada, 2013).
Given the problem of insecurity, coupled with slow economic growth and decline of visitors in tourist regions, some studies have only related tourism to economic growth at an aggregate level, without incorporating its spatial character, an example of this is the work of Loría, Sánchez and Salas (2017). These authors analyze the impacts generated by the tourism growth in employment as determined by Okun's law. On the other way, Andrés-Sarasa (1998) also discusses the importance of tourism but related to women's employment. Further, Balaguer and Cantavella-Jorda (2002) study the economic growth and determine the direct impact that it has had on tourism growth.

Within the empirical evidence, the studies use the econometric technique of Autoregressive Vectors (VAR, for its acronym in Spanish) and its different variants. Unlike those works, this document presents a space panel approach, since we work with census panel information, meaning that there is no time series data available.

\section{Approach to the model and the nature of the data}

\section{The data}

The data used in this work comes from the Economic Census provided by INEGI from 1999 to 2014, as we know, these are census data related to economic activity one year before its publication. The data were deflated at 2008 prices. 
We also use the population census provided by the same institution. We also use information provided by the Executive Secretariat of the National Public Security System. Given that the information on the registry of insecurity in the different areas could be biased to be considered underreported, Fajnzylber et al., (2002) indicate that most crimes are underreported and that the problem is more severe in countries with weak security and judicial systems. For this reason, they argue that homicide is less underrepresented; taking these suggestions into account, in our Violence index was constructed to avoid that bias in information.

\section{Econometric model approach}

In this work, we use spatial econometric techniques developed by authors like Anselin (1988) and Lesage and Pace (2009), where the spatial weights matrix is incorporated as a way to capture the spatial influence. In this way, we can present different types of spatial models, such as the Spatial Autoregressive Model (SAR) that is proposed as follows: $y=\rho W y+X \beta+\varepsilon$; where $y$ is the endogenous variable, $\rho$ is the spillover of the endogenous variable in a set of neighbouring regions (positive autocorrelation), $W$ is a square and positive matrix, its dimension depends on the size of the data sample. The $w_{i j}$ elements are spatial weights, where, in the case of absence of neighboring situation, the weights are zero. The elements of the main diagonal are zero due to the exclusion of the possibility of self. Following Anselin (1988) each element of the matrix is defined as:

$$
w_{i j}=\left\{\begin{array}{c}
1 \text { if } j \in N(i) \\
0 \text { others }
\end{array}\right.
$$

Where $N$ (i) is a set of neighbors $j$. By definition, $w_{i i}=0$. Even though different types of neighborhoods are feasible and it is possible to incorporate different types of variables not limited only to the contiguity, we use the latter criterion. Finally, exogenous variables $X$, which influence the endogenous variable that in our case is the growth of Tourism per capita (GDPTURC) of the municipalities of Guerrero which is based on indexes such as the location coefficient ${ }^{2}$, employed population

\footnotetext{
Authors like Polese (1988), Andrés-Rosales and Villegas (2015), use specialization coefficient indexes for employment, productivity and GDP of the municipalities of Guerrero. The indicators are as follows: Employment Specialization Index (LQ).

Where:

$\mathrm{E}_{\mathrm{i}, \mathrm{r}, \mathrm{i}}$ is the employment in sector $\mathrm{i}$, region $\mathrm{r}$, period $\mathrm{t}$.

$\mathrm{E}, \mathrm{tr}, \mathrm{t}$ is the employment in region $\mathrm{r}$, period $\mathrm{t}$.

$\mathrm{E}_{\mathrm{i}, \mathrm{t}}^{\mathrm{r}, \mathrm{t}}$ is the employment in the sector $\mathrm{i}$ in period $\mathrm{t}$.

${ }_{t}{ }_{t}$ is total employment in period $i$.

A coefficient $L Q>1$ indicates specialization, if $L Q>2$ is considered as a strong conglomeration, and $\mathrm{LQ}<0.5$ is indicative of a low conglomeration.

It is possible that LQ could be high in sectors where there is one or low Number of companies, this is why the LQ is accompanied by an indicator of the number of companies and its occupation level.
} 
index (CLTUR), productivity (IPPTUR), productive specialization (CETUR), and violence indexes (IVIOL, for its acronym in Spanish), the latter constructed by the principal components analysis, which includes variables such as: 1) damage to things; 2) sexual offenses; 3) homicide; 4) injuries; 5) theft, and 6) other crimes. These are categorized and presented in this form by the Executive Secretariat of the National Public Security System (SESNSP3, for its acronym in Spanish), the source of the data used for measuring this indicator. In addition to the tourism sector, the other endogenous variable is the Entity's GDP per capita growth (GDPCTOT).

If the aforementioned spatial dependence is incorporated into the perturbations, it is done as follows: $y=\mathbf{X} \beta$ $+u$, where $u=\measuredangle \boldsymbol{W} u+\varepsilon$. This type of model is known as the Spatial Error Model (SEM). Furthermore, the model known as SARAR is obtained from the union of the SAR and SEM models. However, if we incorporate the impact of the regions as an exogenous variable within the SAR or SEM model, we have: $y=p \mathbf{W} y+\mathbf{X} \beta+\mathbf{W} \mathbf{X} \beta+\varepsilon$, this type of models is known as spatial Durbin Model (SDM).

\section{Exploratory analysis of insecurity and tourism}

Figure 1 shows the evolution of GDP growth and homicides in Guerrero.
What we found is that the growth of the entity has remained constant throughout these periods while that of homicides has skyrocketed, especially since the second quarter of 2008, where it exceeded the dynamics of growth of the entity.

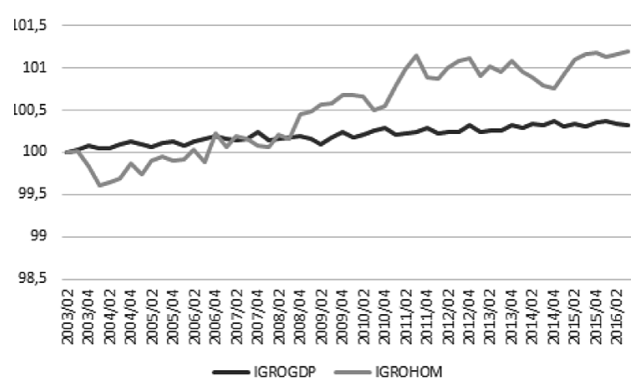

Figure 1. Index of GDP growth and homicides in Guerrero, 2003: 02 to 2016: 04

Source: Own elaboration with information available in INEGI for different years.

Figure 2 shows the violence index of 1999 and 2014, which is used to analyze the spatial agglomeration of insecurity. What we find is that the high-high growth of insecurity occurred in the municipalities of Acapulco de Juárez, Coyuca de Benítez and Chilpancingo de Los Bravos (darker-upper color), while in 2014 there were only two municipalities that were belonging to a violent cluster /o cluster of violence.

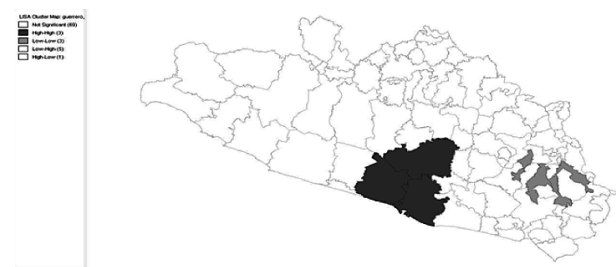

Government website that provides information on insecurity is "Secretariado Ejecutivo del Sistema Nacional de Seguridad Pública" who was consulted for different years. 


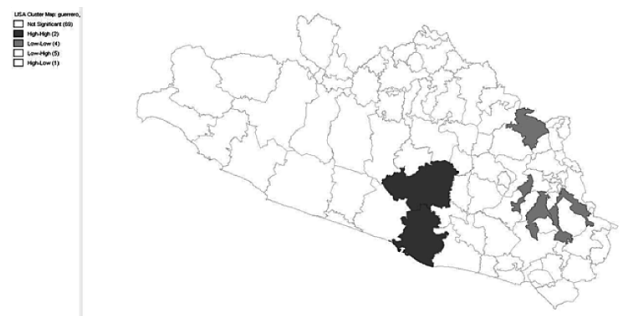

Figure 2. Lisa Cluster map for the violence index, 1999 and 2014

Source: Own elaboration with information available in INEGI for different years.

Acapulco is a tourist area and presents the highest levels of insecurity in crimes such as damages and robberies. The case of Chilpancingo is something particular because it occupies the second place in other crimes and theft within the entity, but being an area not focused on tourism, the crimes committed in this municipality are different and basically are made in theft in public transport and assault by armed hand. Although homicides have also increased notably in recent years, which is why it is ranked as the second most violent municipality in the state according to SESNSP data

\section{Empirical evidence of insecurity and tourism}

Two types of models were estimated for the empirical evidence of this work, where the violence and growth rate of total crimes are exogenous variables. For these cases, we use the Spatial Panel Data (SPD), and the model is known as Spatial Durbin Model (SDM), which can be used to obtain direct, indirect and total impacts.
In table 1 we present the main findings. The models (1-2 and 5-6) Correspond to the tourism GDP growth in the area as an endogenous variable, while in models 3-4 and 7-8 we use the total GDP of the region as the endogenous variable. In both cases, the violence index and total crimes are one of the exogenous variables. We find the following stylized facts and present them in the form of direct, indirect and total impacts, first for the tourism sector growth, and then for the GDP growth.

1) Regarding the tourism sector growth in the region (models 1-2 and 5-6):

a) Direct impacts: the variables of tourism specialization coefficient (CETUR) and wages coefficient (REMTUR) were not significant for any of the models estimated in this work. This implies that the tourism specialization and perceived remunerations have not influenced the growth of the tourism sector neither the growth of the entity. The location coefficient, which measures the employment concentration in the region, has a positive and significant impact on tourist production growth in the entity since it has a direct impact on this variable in almost 0.614 and 0.644 in the SARAR and SDM model estimates, respectively. On the other hand, the productivity index of the sector (IPPTUR) has positively influenced the tourism production growth $(0.361$ and 0.379). In the estimates mentioned above, we do not find empirical evidence that violence and total crime 
directly influenced the tourism GDP growth, since the variables were not statistically significant.

b) Indirect impacts: The findings point out that the increase in violence within the neighbors of a given region tend to positively influence their growth (0.054), which indicates that the increased violence of the residents of a region influence $0.05 \%$ in the growth of a region while the total crimes do in $0.03 \%$. The location coefficient has a negative impact on tourism growth in a given region in -0.239 and -0.234 ; the same happens with the wages (-0.045 and -0.044).

c) Total impacts: The study indicates that the final or total impacts in the region can be higher or lower depending on the direct and indirect impacts. For example, the impact of tourism specialization has a value of -0.04 , which means that it has a negative influence on tourism production growth, while wages have barely changed it by 0.07 and vio- lence index does in -0.09 units on the average growth of tourism.

2) GDP growth in the region (models 3-4 and 7-8).

a) Direct impacts: The study shows that the direct impacts of the tourism sector location on the growth of the region has been negative and is around $-1.2 \%$ to $-1.5 \%$, while productivity has a positive impact on this variable by nearly $0.6 \%$. Violence and total crime decrease economic growth by $0.36 \%$ and $0.87 \%$, respectively.

b) Total impact: the total impact of employment specialization adversely affects the growth of the entity, indicated by the value of the coefficients (-0.05 and -0229). The remuneration does it positively, the same as the productivity of the tourism sector. What is important to note is that violence has negatively affected the growth of the region by $0.2 \%$, while total crimes have negatively affected $1.4 \%{ }^{4}$.

Table 1. Spatial Panel Data estimation, 1999 and 2014

\begin{tabular}{|c|c|c|c|c|c|c|c|c|}
\hline \multirow{3}{*}{ Contiguity } & \multicolumn{4}{|c|}{ Violence index } & \multicolumn{4}{|c|}{ Total offences } \\
\hline & \multicolumn{2}{|c|}{ GDPTURC (1) } & \multicolumn{2}{|c|}{ GDPTOTC (2) } & \multicolumn{2}{|c|}{ GDPTURC(3) } & \multicolumn{2}{|c|}{ GDPTOTC(4) } \\
\hline & SARAR & SDM & SARAR & SDM & SARAR & SDM & SAR & SDM \\
\hline \multicolumn{9}{|c|}{ Direct impacts } \\
\hline \multirow[t]{2}{*}{ CETUR } & -0.064 & -0.067 & -0.081 & -0.085 & -0.061 & -0.064 & -0.136 & -0.142 \\
\hline & $(-0.94)$ & $(-0.9)$ & $(-0.78)$ & $(-0.73)$ & $(-0.9)$ & $(-0.76)$ & $(-0.91)$ & $(-0.83)$ \\
\hline \multirow[t]{2}{*}{ CLTUR } & $0.614^{* * *}$ & $0.644^{* * *}$ & $-1.268^{* * *}$ & $-1.341 * * *$ & $0.611^{* * *}$ & $0.64 * * *$ & $-1.512 * * *$ & $-1.573 * * *$ \\
\hline & $(3.89)$ & $(3.92)$ & $(-4.94)$ & $(-4.8)$ & $(3.83)$ & (3.95) & $(-4.36)$ & $(-4.24)$ \\
\hline REMTUR & 0.117 & 0.122 & 0.147 & 0.155 & 0.115 & 0.12 & 0.098 & 0.102 \\
\hline
\end{tabular}

This may be due to the multiplier effects in the region, where insecurity first influences the tourism sector, but at the aggregate level it indirectly impacts on the primary and secondary sectors due to low demand of these goods. 


\begin{tabular}{|c|c|c|c|c|c|c|c|c|}
\hline \multirow{3}{*}{ Contiguity } & \multicolumn{4}{|c|}{ Violence index } & \multicolumn{4}{|c|}{ Total offences } \\
\hline & \multicolumn{2}{|c|}{ GDPTURC (1) } & \multicolumn{2}{|c|}{ GDPTOTC (2) } & \multicolumn{2}{|c|}{ GDPTURC(3) } & \multicolumn{2}{|c|}{ GDPTOTC(4) } \\
\hline & SARAR & SDM & SARAR & SDM & SARAR & SDM & SAR & SDM \\
\hline & $(1.46)$ & $(1.42)$ & $(1.16)$ & $(1.09)$ & $(1.42)$ & $(1.4)$ & $(0.57)$ & $(0.54)$ \\
\hline \multirow[t]{2}{*}{ IPPTUR } & $0.361 * * *$ & $0.379 * * *$ & $0.619 * *$ & $0.655^{* * *}$ & $0.361 * * *$ & $0.378 * * *$ & $0.669 * * *$ & $0.695^{* * *}$ \\
\hline & $(6.65)$ & $(6.77)$ & $(7.23)$ & $(6.99)$ & $(6.54)$ & $(6.04)$ & $(5.78)$ & $(5.95)$ \\
\hline \multirow[t]{2}{*}{$\mathrm{IVIOL}$} & -0.14 & -0.147 & -0.34 & $-0.36^{* *}$ & & & & \\
\hline & $(-1.2)$ & $(-1.16)$ & $(-1.94)$ & $(-2.11)$ & & & & \\
\hline \multirow[t]{2}{*}{ DELTOT } & & & & & -0.1 & -0.105 & -0.844 & $-0.878^{* * *}$ \\
\hline & & & & & $(-0.68)$ & $(-0.63)$ & $(-2.74)$ & $(-2.61)$ \\
\hline \multicolumn{9}{|c|}{ Spatial correlation } \\
\hline \multirow[t]{2}{*}{ lambda } & $0.436^{* * *}$ & & $0.809 *$ & & $0.42 * * *$ & & & \\
\hline & $(3.01)$ & & $(14.24)$ & & $(2.81)$ & & & \\
\hline \multirow[t]{2}{*}{ rho } & $-0.515 * * *$ & & $-0.557 * * *$ & & $-0.504 * * *$ & & $0.404 * * *$ & \\
\hline & $(-2.85)$ & & $(-3.84)$ & & $(-2.73)$ & & $(4.81)$ & \\
\hline \multicolumn{9}{|c|}{ Indirect impacts } \\
\hline \multirow[t]{2}{*}{ CETUR } & & 0.025 & & $0.033 * *$ & & 0.023 & & $-0.087 * * *$ \\
\hline & & $(0.82)$ & & $(0.71)$ & & $(0.66)$ & & $(-0.72)$ \\
\hline \multirow[t]{2}{*}{ CLTUR } & & $-0.239 * *$ & & $0.527 * * *$ & & $-0.234 * * *$ & & $-0.967 * * *$ \\
\hline & & $(-2.24)$ & & $(3.32)$ & & $(-2.19)$ & & $(-2.31)$ \\
\hline \multirow[t]{2}{*}{ REMTUR } & & $-0.045^{* * *}$ & & $-0.061^{* * *}$ & & $-0.044^{* * *}$ & & $0.062^{* * *}$ \\
\hline & & $(-1.21)$ & & $(-1.01)$ & & $(-1.21)$ & & $(0.45)$ \\
\hline \multirow[t]{2}{*}{ IPPTUR } & & -0.14 & & -0.257 & & -0.138 & & 0.428 \\
\hline & & $(-2.54)$ & & $(-3.76)$ & & $(-2.35)$ & & $(2.53)$ \\
\hline \multirow[t]{2}{*}{\begin{tabular}{|l}
$\mathrm{IVIOL}$ \\
\end{tabular}} & & $0.054 * *$ & & $0.141^{* * *}$ & & & & \\
\hline & & $(1.02)$ & & $(1.87)$ & & & & \\
\hline \multirow[t]{2}{*}{ DELTOT } & & & & & & $0.038 * *$ & & $-0.54 * *$ \\
\hline & & & & & & $(0.59)$ & & $(-1.92)$ \\
\hline \multicolumn{9}{|c|}{ Total impacts } \\
\hline \multirow[t]{2}{*}{ CETUR } & & $-0.042 * *$ & & $-0.052 * * *$ & & $-0.04^{* *}$ & & $-0.229 * *$ \\
\hline & & $(-0.9)$ & & $(-0.72)$ & & $(-0.77)$ & & $(-0.8)$ \\
\hline \multirow[t]{2}{*}{ CLTUR } & & 0.405 & & -0.814 & & 0.406 & & -2.54 \\
\hline & & $(3.54)$ & & $(-4.29)$ & & $(3.52)$ & & $(-3.5)$ \\
\hline \multirow[t]{2}{*}{ REMTUR } & & $0.077^{* *}$ & & $0.094 * * *$ & & $0.076 * *$ & & $0.165 * *$ \\
\hline & & $(1.39)$ & & (1.09) & & $(1.37)$ & & $(0.52)$ \\
\hline IPPTUR & & 0.238 & & $0.397 *$ & & 0.239 & & $1.124 *$ \\
\hline & & $(5.3)$ & & $(5.54)$ & & $(4.92)$ & & $(4.33)$ \\
\hline $\mathrm{IVIOL}$ & & $-0.092 * * *$ & & $-0.218 * * *$ & & & & \\
\hline & & $(-1.16)$ & & $(-2.07)$ & & & & \\
\hline DELTOT & & & & & & $-0.067 * * *$ & & $-1.418^{* * *}$ \\
\hline & & & & & & $(-0.62)$ & & $(-2.47)$ \\
\hline
\end{tabular}

Source: Developed by the authors using data from the Economic Censuses 1999, 2004, and 2009 from National Institute of Statistics and Geography. Notes: $\left({ }^{*}\right)$ statistically significant at $1 \%$; $\left({ }^{* *}\right)$ statistically significant at $5 \% ;\left({ }^{* * *}\right)$ statistically significant at $10 \%$. 
It can be observed that the spillover effect of tourism in the region is not significant, but the growth of the region is 0.404 , which implies that the economic growth causes a spillover effect in the regions of $0.4 \%$, this does not happen with the tourism sector growth.

\section{Conclusions}

One of the cities most visited by national and international tourism in addition to Cancun is Acapulco in the state of Guerrero that has been considered one of the most violent at a global level because of the increase in insecurity in this city. This consideration has influenced the flow of international visitors as we show with the empirical evidence in this work. Findings indicate that Acapulco and Chilpancingo present an insecurity agglomeration, meaning that the violence impact on tourism activity in the region has been highly significant, but this effect is much more meaningful when referring to the growth of the entity as a whole, rather than only to the touristic activity.

Furthermore, we show that violence and total crimes do not influence the GDP growth of the tourist sector directly, although they do so for the growth of the region. However, the overall impact of these two variables is negative, which means that the violence affects tourism and economic growth. The effect is less on the tourism sector $(-0.09 \%$ for violence and $-0.06 \%$ for total crimes), and greater in the growth of the whole region $(-0.2 \%$ and $-1.4 \%$, respectively).

It is important to emphasize that tourism is the primary determinant of the growth of Guerrero, especially Acapulco, a seasonal tourism from which people obtain an income that complements their main activities such as agriculture or fishing. Also, many people get temporary jobs in times of low tourist influx, knowing that when it is a holiday season they can have a surplus that can be used to subsist in the former. However, the insecurity mentioned in this document has removed Acapulco from its position of a famous tourist destination, not only with decreases in income during high affluence seasons but also throughout the whole year. This phenomenon impacts negatively the growth of the region.

Evidence suggests that multinational corporations in old globalized extractive industries have accumulated significant experience with difficult regional conditions, including violent conflict and crime (International Peace Academy, 2001; Bennett, 2002). These companies can absorb the cost generated by the increased insecurity in a region. On a different scenario, even if tourism companies could absorb the cost, the decrease in income due to the low influx of tourists would make it unfeasible.

From the previously mentioned arguments, we can suggest several factors that could happen within a region: Migration caused by criminal activities, 
decreases in personal consumption (Cullen and Levitt, 1999), reduction in personal use (Mejía and Restrepo, 2010), and relocation and closure of companies (Greenboum, Dugan and Lafree, 2007), given the fact that retail companies are largely affected by criminal organizations and extortion as firms in the retail sector are more likely to be victims of criminal organizations through blackmail and intimidation (Daniele and Marani, 2011).

It is crucial not only to take actions to protect the state of Guerrero but to do so with all the country since it is the same crime pattern that affects most of the states of the nation, where insecurity affects the production and population. Furthermore, it is vital to prevent the country from entering into a vicious circle, by taking live actions to improve citizen security.

\section{References}

Alfaro Navarro, J. L. and López Ruiz, V. R. (2008). El capital estructural tecnológico como medida de crecimiento económico regional. Estudios de economía aplicada, 26(3), 57-72.

Almirón, A., Bertoncello, R., Kuper, D. and Ramírez, L. (2008). El turismo como impulsor del desarrollo en Argentina: una revisión de los estudios sobre la temática. Aportes y Transferencia, 12(1), 57-86.

Andrés-Sarasa, J. L. (1998). Turismo y empleo femenino. Cuadernos de Turismo, (1), 9-27.
Anselin, L. (1988). Spatial econometrics methods and models. California: Kluwer Academic Publishers.

Balaguer, J. and Cantavella-Jordá, M. (2002), Tourism as a long-run economic growth factor: the Spanish case. Applied economics, 34(7), 877-884

Bennett, J. (2002). Multinational Corporations, social responsibility and conflict. Journal of International Affairs, 55(2), 396-410.

Czamanski, S. (1973). Model of Urban Land Allocation. Growth and Change: A Journal of Urban and Regional Policy, 4(1), 43-48.

Cullen, J. B. and Levitt S. D. (1999) Crime, urban flight, and the consequences for the cities. The Review of Economics and Statistics, 81, 159-169.

Daniele, V. and Marani, U. (2011). Organized crime, the quality of local institutions and DFI in Italy: a panel data analysis. European Journal of Political Economy, 27, 132-142.

Estrada, J. L. (2013). Democracia, Estado y seguridad ciudadana. Descripción teórica sobre la ruptura en el paradigma del Estado como garante exclusivo de la seguridad. Democracia, Estado y Seguridad Ciudadana, 84, 365-384.

Fajnzylber, P., Lederman, D. and Loaza, N. (202). Inequality and violent crime, The Journal of Law and Economics, 45(1), 1-40.

Figueroa, L., Montes de Oca, R., Artavia, R. and Marshall, L. (1997). Impacto de la inseguridad pública sobre el clima de negocios e inversión de centroamérica. Recuperado 
de https://www.incae.edu/ES/clacds/ publicaciones/pdf/cen900filcorr.pdf

Fujita, M. (2000). Thünen and the new economic geography. Disussion Paper No. 521, Kyoto Institute of Economic Research. Recuperado de http://www.rieti.go.jp/jp/publications/dp/11e074.pdf

Instituto Nacional de Estadística y Geografía (INEGI) (s. f.). Censos económicos. Recuperado de http://www. beta.inegi.org.mx/app/saic/default. aspx

Greenboum, R.T., Dugan, L. and Lafree, G. (2007). The impact of terrorisms in Italian employment and business activity. Urban Studies, 44, 1093-1108.

Kaldor, N. (1984). Causas del lento ritmo de crecimiento del Reino Unido. Investigación Económica, XLIII(167), 9-24.

Lesage, J. and Pace, K. R. (2009). Introduction to spatial econometrics. London: CRC Press, Taylor and Francis Group.

Loria, E., Sánchez, F. and Salas, E. (2017). Efectos de la llegada de viajeros internacionales en el desempleo y el crecimiento económico de México 2000.2-2015.2. El Periplo Sustentable, (32), 1-24.

Mejía, D. and Restrepo, P. (2010). Crime and Conspicouos Consupmtion. Centro de Estudios Sobre el Desarrollo Económico, Documento No. 32, p. 1-49.

Polanco, G. M. and Torres, P.V. (2017). Criminalidad y competitividad de los destinos turísticos de México. En M. Á. Tinoco-Zermeño, V. H. Torres-Preciado and Venegas-Martínez. F. (Eds.), Los desafíos de la economía mexicana, el sector externo I (pp. 223-244). México, d. F.: IPN.

Polèse, M. (1998). Economía urbana y regional: introducción a la relación entre territorio y desarrollo. Colima: Universidad de Colima.

Roemer, A. (2012). Economía del crimen. México, D. F.: Noriega.

Richardson, H. W. (1986). Economía regional y urbana. Madrid: Alianza.

Sánchez, L. F. and Cruz, M. J. N. (2016). Determinantes económicos de los flujos de viajeros a México. Revista de Análisis Económico, 31(2). 3-36.

Sánchez, L. F. and Cruz, M. J. N. (2017). Excursionismo internacional y secuestros en la frontera de México, 1997-2016. Revista de Relaciones Internacionales, Estrategia y Seguridad, 12(1), 237-266. doi: http:// dx.doi.org/10.18359/ries.2471

Sánchez, L. F. and Cruz, M. J. N. (2015). Efecto de los secuestros en la recepción de excursionistas en crucero. Un estudio para México, 1997.1 2014.3. En XX Congreso Internacional de Contaduría, Administración e Informática. Universidad Nacional Autónoma de México, México D. F.

Vázquez-Barquero, A. (2006). Surgimiento y transformación de clústeres y milieus en los procesos de desarrollo. Revista Latinoamericana de Estudios Urbano Regionales, XXXII (95) 75-92. 